\title{
A mobile application for working on university service learning: usability, adequacy and perceptions of usefulness
} \author{
adecuación y percepciones de utilidad \\ María Santágueda Villanueva; santague@uji.es \\ María Ángeles LLopis Nebot; mallopis@uji.es \\ Francesc Marc Esteve Mon; festeve@uji.es \\ Universitat Jaume I (Spain)
}

Una aplicación móvil para trabajar en el aprendizaje servicio universitario: usabilidad,

\begin{abstract}
In the current context, we not only need to train digitally competent students, but to develop civic and citizenship skills. One methodology for this is Service Learning (SL),. Mobile devices can enable the design of SL activities that take advantage of digital capabilities. However, experiences are still scarce.
\end{abstract}

In the present research, a mobile application for $\mathrm{SL}$ is presented, with which students and teachers are in constant interaction, where feedback is constant and learning is reciprocal. In this article, and based on a DBR methodology, we evaluated technological usability, pedagogical usability and satisfaction. For this purpose, 3 teachers and 11 students of the Education degrees, used and evaluated the application using the usability test and conducting several interviews.

According to the results obtained, the application works correctly and meets the four levels of usability. However, both students and teachers detected elements for improvement, especially in design. The application presented allows further progress towards eSL, taking advantage of the possibilities of hybrid technologies and scenarios.

Keywords: mobile application; validation; pedagogical usability; service-learning; preservice teachers

\section{Resumen}

En el contexto actual no solo necesitamos capacitar a estudiantes digitalmente competentes, sino desarrollar habilidades cívicas y ciudadanas. Una metodología para ello es el Aprendizaje Servicio (ApS). Los dispositivos móviles pueden permitir el diseño de actividades ApS que aprovechen las potencialidades digitales. Sin embargo, las experiencias son todavía escasas.

En la presente investigación se presenta una aplicación móvil para ApS, con la cual los alumnos y profesores están en constante interacción, y donde la retroalimentación es constante y el aprendizaje es recíproco. En este artículo, y a partir de una metodología de DBR, evaluamos la usabilidad tecnológica, usabilidad pedagógica y satisfacción. Para ello, 3 profesores y 11 estudiantes de los grados de Educación usaron y evaluaron la aplicación utilizando el test de usabilidad y realizando varias entrevistas. Según los resultados obtenidos, la aplicación funciona correctamente y cumple los cuatro niveles de usabilidad. Aunque tanto el alumnado como el profesorado detectó elementos de mejora, sobre todo de diseño. La aplicación presentada permite seguir avanzando hacia el ApS, aprovechando las posibilidades de las tecnologías y los escenarios hibridos.

Palabras clave: aplicación móvil; validación; usabilidad pedagógica; aprendizaje-servicio; profesorado en formación. 


\section{INTRODUCTION}

The creation of the European Higher Education Area (EHEA) led to a chance to change and encourage improvement in Spanish universities, especially between the years 2005 and 2010 (Calvo-Bernardino \& Mingorance-Arnaiz, 2009; Palma, 2019). Beyond facilitating the compatibility and the movement between European universities, this process was a major paradigm shift in the field of university education, towards more active teaching (Palomares, 2011), and the emphasis on the necessary competencies that students had to develop through college (Salaburu et al., 2011; Villa \& Poblete, 2011), to address the needs of society.

In the framework of these competencies, on the one hand, some authors emphasise the need to develop civic competences and citizenship along with their university training (Garcia, et al., 2010; Santos \& Lorenzo, 2012; Touriñán, 2007). According to the European Commission (2018), this is the ability to act as responsible citizens and fully participate in social and civic life, taking into account the social, economic, legal and political rights that this entails. On the basis of this assumption, citizenship education becomes a priority need in training students in the higher education context (Print, 2003). This growing interest in serving society, as well as the greater commitment of improving student learning, has led to the introduction of service learning (hereinafter SL) as an innovative methodology in colleges and universities (Soskin et al., 2010).

On the other hand, different administrations and institutions highlight the need to rethink new strategies and methodologies to address the digital demand of today's society, including the acquisition of digital competence (European Commission, 2018; Vuorikari et al., 2016). A digital competence which involves the combination of knowledge, skills and attitudes that are required to use digital technologies in an appropriate safe, critical, and responsible manner for learning, work or participating in society (Ferrari, 2012; Nawaz \& Kundi, 2010).

This all becomes especially relevant if we focus on the training of future teachers. Education cannot be understood as the mere application of methodologies of a technical type, rather it must be conceived from a humanistic and interpretative approach of knowledge, in which learning comes from the construction of meaning. The role of the teachers cannot be limited to the mere reproduction of closed models, in the development of their praxis they must be able to create and design in order to adapt to students. In the same way, we comprehend that teachers in an increasingly digital world must understand that technology is a tool at the service of their own educational ends, at the same time as a way of relating to the world, human actions and a source of values (De Vries, 2016). From this perspective, digital competence is understood from a holistic point of view that is in constant development (Esteve et al., 2018).

After analysing the demands required by $S L$ in the field of training future teachers and taking into account the current characteristics of university students, the main objective of this study is to explore the possibilities of mobile technology in this type of formative processes. Following the approaches of Plomp and Nieveen (2009) for educational research based on design, this research describes the creation and review of the usability of a mobile application, in order to improve the processes of SL, in the study of the teaching degrees in Early Childhood Education and Primary Education. 


\section{THEORETICAL FRAMEWORK}

\subsection{Service Learning (SL) in the digital society}

SL is an active methodology that places the student as the central figure of the teachinglearning process. The student comes in contact with a real social context in which there is an unmet need and has to mobilise academic knowledge, resources and personal strategies to improve this reality. As fruits of this intervention, a personal and social knowledge that goes beyond the technical learning of content is achieved (Chiva-Bartoll \& Gil-Gomez, 2018).

Zorrilla (2017) identifies a series of defining characteristics of SL. On the one hand, it is described as an active and experiential methodology, located in a constructivist learning framework, by handing the student the decision-making process that habitually resides with the teacher and thus converting them into agents of their own learning. On the other hand, SL may be understood as a methodology of globalisation that is comprised of many teachinglearning strategies such as problem-based learning or cooperative learning. It has a marked social character, since, in its application, it is expected to improve a previously detected collective need, in combination with the active learning of curricular content.

The proper application of SL cannot be dissociated from the students' own curriculum (Zorrilla, 2017). It must be linked in its structure to the learning contents of a particular subject so as not to undermine the very essence of its methodology. The curriculum, applied to a particular context and need, allows students to not only learn practice but reflect on it, challenging knowledge and previous beliefs and extracting their own pedagogical principles of teaching and learning. In sum, the result of the reflection allows a more realistic view of the profession to be obtained.

With all of the above, SL needs the creation of social networks that for one thing allow the detection of needs and, nevertheless, put adequate logistics in place to underpin its application. In this regard, the mobile phones and other devices available today are of great use, both for their high social penetration as for their ubiquity and versatility. The need to rely on technology is related to the vision of connectivist learning (Siemens, 2004), that appreciates that such learning happens in diffuse environments whose changing elements allow the individual to manage knowledge and establish connections to sets of specialised information and that the field of education facilitates the design of new learning environments. Likewise, Santos-Rego et al. (2020), defend the opportunity to combine SL with tools and pedagogical programmes in higher education, giving rise to new hybrid SL models in which technology is used to establish communication networks that strengthen the role of the student. The introduction of technology in this case does not redefine the traditional conception of SL, but establishes it as a differentiated modality in which technology mediates subject participation and the advance of the project.

\subsection{Mobile learning and its educational potential}

More and more students and teachers use mobile devices in a variety of contexts to achieve a wide variety of learning objectives (or mobile learning), since this technology allows access to information at any time and from any location, or the creation of content, or the generation of 
knowledge networks, favouring the development of innovative educational practices (Camacho \& Esteve, 2018). In addition, mobile devices are becoming more affordable, prior learning is not a requirement, maintenance is light, and they are easy to use in education (Mylläri et al., 2011).

As Mac Callum et al. (2014) point out, the level of digital competence or attitudes toward the use of technology are among the key factors in the take up of mobile learning. This digital competence, in the case of teachers and future teachers, not only involves the ability to mobilise the knowledge, skills and attitudes to efficiently and effectively use information and communications technology (ICT), but also to improve and transform classroom practice, enriching one's own professional development and identity, as well as the students' (Hall, et al., 2014; Krumsvik, 2009).

In keeping with Ramos et al. (2009), it can be said in the case of the current students that they are intensive users, who, in addition to owning these types of devices, use them constantly. This makes it easy for us to access the movement of knowledge in any place and at any moment, since smartphones now offer resources comparable to those of a computer. As was described in the report of Technological Prospective: Higher Education in Latin America 2012-2017, mobile devices are an emerging technology that will have a significant impact on education (Durall et al., 2012). In fact, mobile learning facilitates simple and immediate student access to different resources and materials, the ability to participate in their creation, to comment on them and to share them in real-time, generating knowledge networks and reflection (Chou et al., 2012). According to Gikas and Grant (2013) or Ozdamli and Uzunboylu (2014), these mobile devices can have a special impact on learning through active, communicative, interactive, and collaborative teaching strategies. In a similar vein Ciampa (2014) argues that these devices can lead to a sense of curiosity and challenge, as well as the creation of cooperative activities and competitiveness, which tend to be very motivating to the student.

As evidenced by Camacho and Esteve (2018), the variety of activities carried out with mobile devices is far-reaching, both at the content level, as well as in the methodologies and applications used. There are currently multiple Apps for educational purposes, or for classroom use, taking advantage of the search options, GPS location information, audio and video recording, or communication with others. The mobile application we are going to evaluate was presented in Santagueda-Villanueva et al. (2019).

\subsection{The technological and educational usability of a mobile application}

Usability, according to Keinonen (1998), is the set of characteristics associated with the product design process; the product itself, the use of the product, the user experience with the product or the expectations of users.

At the technological level, different agencies and standards appear that seek to ensure such usability, as is the case of the International Organization for Standardization (ISO). According to Seffah et al. (2006), we can highlight the following ISO standards or models of usability: (1) ISO 9241-11 (1998), which is the most widely used model for mobile usability also (Kunjachan, 2001), and identifies efficiency, effectiveness and satisfaction as key attributes; (2) ISO / IEC 9126-1 (2001), which defines usability as a quality attribute of software made up of the five factors of understandability, learnability, operability, attractiveness, and usability compliance; 
(3) ISO / IEC 9126-4 (2001), which defines the concept of quality in use; and (4) ISO / IEC 145981 (1999), which allows the measure of quality in use from the perspective of the internal attributes of software quality. Despite the different standards, according to Kunjachan (2001), the central concept of usability always seems to be ISO 9241-11 and the characteristics of usability of the rest depend on the interface type that is considered.

While the criteria for assessing the usability of technology have been extensively detailed and analysed, the pedagogical aspects for the design or the use of resources or digital materials have been studied much less frequently (Nokelainen, 2006).

At the educational level, usability has traditionally been limited to measure the time and effort to complete a particular task, performance, or user satisfaction. However, in recent years, adding criteria such as efficiency, reliability, or consistency, along with components of pedagogical usability, like motivation, learner control, feedback, and learner activity are also proposed (Nokelainen, 2006). When we are in educational environments, usability should be understood differently. Pedagogical usability depends, therefore, on the set aims of the learning situation on the part of the student body and faculty, which allows us to relate the usability and pedagogical design (Eshed, 2014). In this same sense, Tahir and Arif (2014) point out that traditional approaches to usability have changed. According to these authors, this is defined by the characteristics of: (1) effectiveness, which implies the interactivity, navigation, feedback and understanding of messages; (2) efficiency, which takes into account the time required, the effort, the cognitive load or the educational value, (3) the operability, i.e., the customisation of the interface, the readability of the text or the feeling of control; and (4) the satisfaction, which includes engagement, design and graphic appeal. This model of usability as proposed by Tahir and Arif (2014) is that which we will take as the reference in the present investigation.

\section{THE RESEARCH DESIGN}

The present study is part of an Educational Design Research (EDR), a variant of the well-known Design-Based Research (DBR) methodology applied to the world of education (Plomp \& Nieveen, 2009; Van den Akker et al., 2006). According to these authors, this methodology is understood as a systematic process of analysis, design, development, and evaluation of an educational intervention (in this case, a strategy for the implementation of SL using a mobile app) as a solution to a complex educational problem. In addition to solving that problem, the EDR methodology seeks to develop a series of design principles that can guide and can be implemented in other similar contexts.

\subsection{The research context}

The research was carried out during the year 2019, in a medium-sized Spanish university (close to 12,000 students and 1,400 teachers). More specifically, development took place in the Early Childhood Education and Primary Education Teaching Degrees, linked to the subject of Teaching of Bodily Expression. 
According to different authors, the subjects related to the Teaching of Bodily Expression are considered suitable for applying SL, both for the high degree of procedural teaching that these subjects work on and the amount of interactions that it makes possible, obtaining multiple beneficial effects in both the social groups with which they work (Galván \& Parker, 2011; Himelein et al., 2010; Marave-Vivas et al., 2019), as well as in the academic, personal and social fields of the agents who apply it, in this case, of the future teachers (Carrington \& Saggers, 2008; Chambers \& Lavery, 2012; Conner, 2010; Miller \& Gonzalez, 2010).

\subsection{The educational intervention of SL through SL Mobile App}

In the present investigation, the direct recipients of the SL service are different associations and local institutions, whose common bond is their attention to collectives with functional diversity. This means that the pupils of the Teaching Degrees in Elementary and Primary Education, organised by groups, must travel to these places to run the project, within a timetable that varies according to the entity.

After an initial visit, students must design the educational intervention they are to develop during their SL. To do this, and as described below, they should make use of the SL mobile App, the app developed for the present investigation (Figure 1).

Figure 1.

Evolution of the prototype version of SL mobile App (Source: own elaboration).
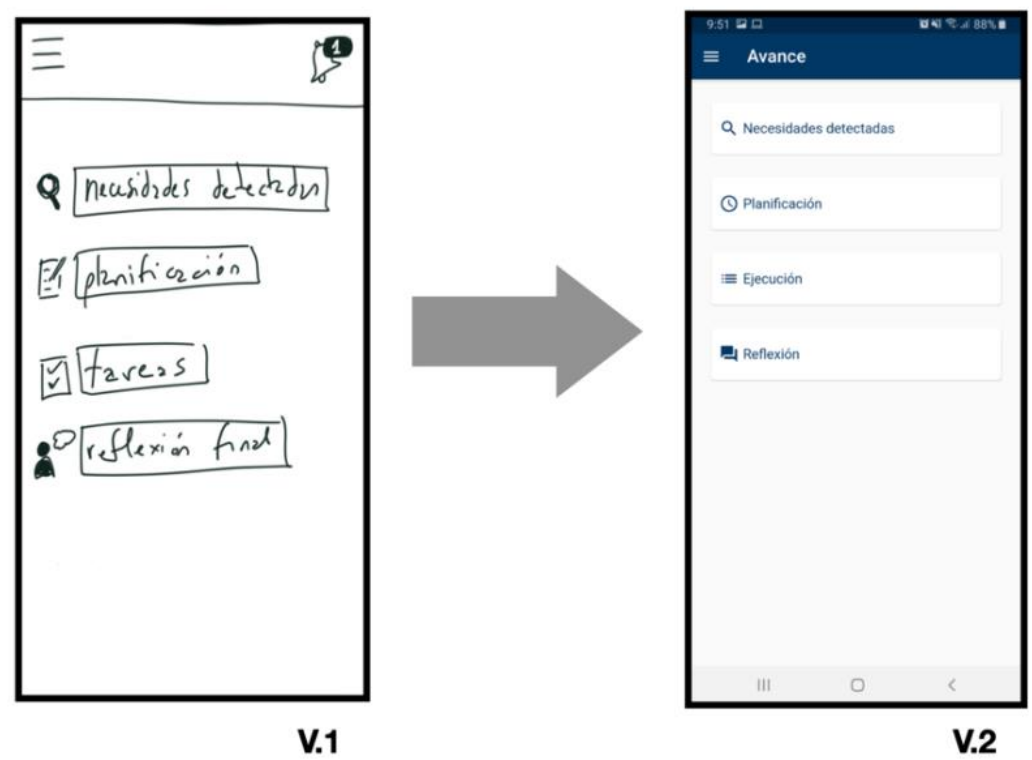

The main screen of the application displays the four basic options, according to the model described in Santagueda-Villanueva et al. (2019): (1) needs detection, (2) task planning, (3) task development or execution, and (4) final reflection. The application was developed by an external company to our University (www.faytheconsulting.com). In Figure 2, we show some screens, in the left the students mark the detection needs and the centre and the rights, the students can programme the different tasks. Finally, in the Figure 3 , in the left, the students 
show the execution which texts, photos, videos or audio, and the right the students make the final reflection which the same tools.

\section{Figure 2.}

Different screens: left detection; centre and right task planning (Source: own elaboration).

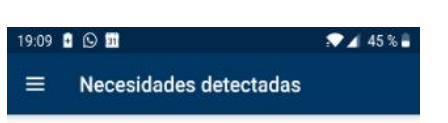

Competencias

Participar en las propuestas de mejora en los distintos ambittos de actuación Adquirir un conocimiento práctico del Aplicar conocimientos básicos sobre las nuevas tecnologias de la información y lia contexto informativo actualizado a fin de conocer los avances de la educación fisica y el deport

Conocer formas de colaboración con los distintos sectores de la comunidad Conochy del entorno social: Conocer y aplicar los procesos de
interacción y comunicación en el aula, as como dominar las destrezas y habilidades sociales necesarlas para aprendizaje y la convivencia. Conocery distingut los diferentes instrumentos de evaluación y utilizarlos mejora de su práctica docente Controlar y hacer el seguimiento del
proceso educativo y, en particular, de
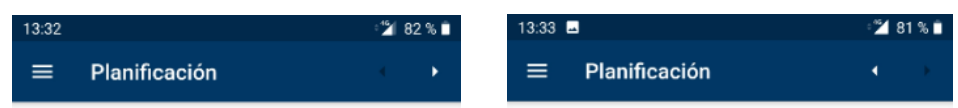

Tareas

\begin{tabular}{l} 
Nueva tarea \\
Nombre \\
\hline Responsables \\
\hline Fecha inicio \\
\hline Fecha fin \\
\hline
\end{tabular}

¿Qué aprenderé?

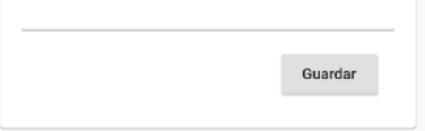

Figure 3.

Different screens: left execution and right finally reflection (Source: own elaboration).
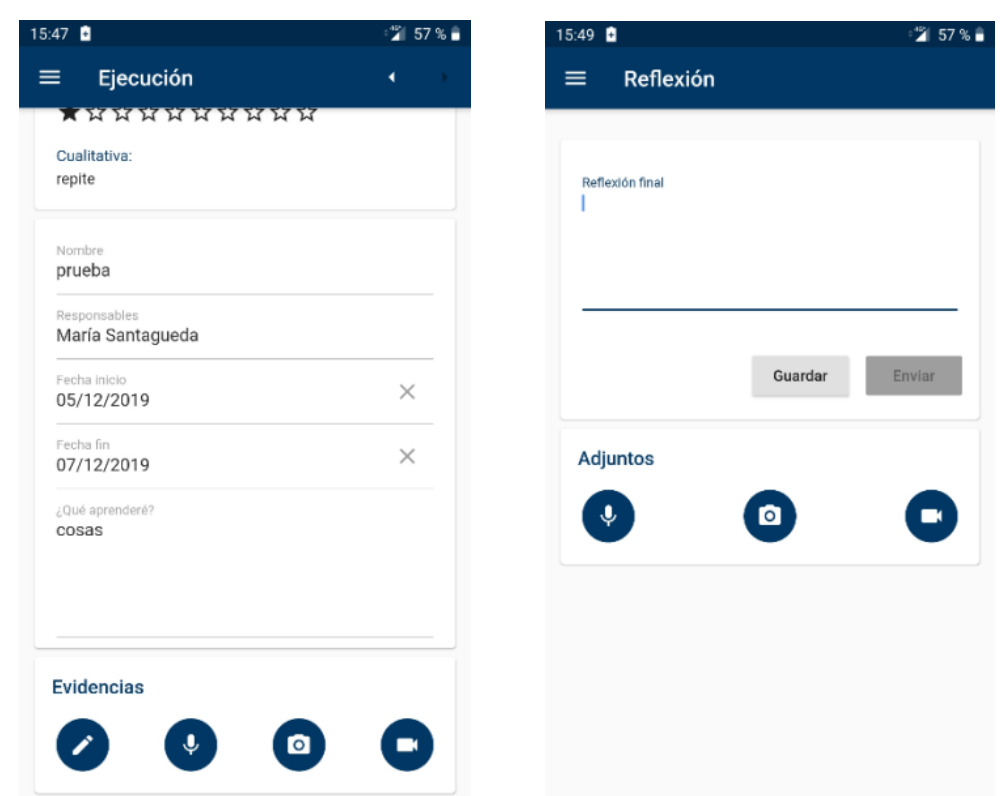

Adjuntos

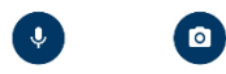

Each student or group of students must have their own mobile device on them, with the SL mobile App previously installed. After completing each step, the tutor receives a notification and must validate the student made proposal, to be able to move on to the next step. This fact 
makes the flexibility to adapt to the students' times and spaces the key management factor. To combine both elements is not easy, especially with the large number of university students who simultaneously participate. For the faculty, correctly monitoring the entire methodological process of participating groups when they are operating outside the classroom is a challenge.

\section{PARTICIPANTS}

The pilot group was composed of 125 Elementary and Primary Education Teaching Degrees students. However, given that the prototype of SL mobile App (v.2) could only be installed on Android mobile devices, the participation was reduced to 66 students (39\% male and $61 \%$ female), with an average age of 19 years. In addition, three subject tutors also participated, a woman and two men.

\subsection{Instruments and process of collecting the information}

As suggested by Dede et al. (2004), quantitative and qualitative methods are used to analyse this type of experiences, from a sample of key informants and potential users (Tessmer, 1993), by means of a systematic procedure for collecting information as described below.

To analyse the educational usability of SLApp, the usability questionnaire proposed by Tahir and Arif (2014) was used, consisting of 35 items evaluated using a Likert-type scale of 5 alternatives, 1 being "strongly disagree" and 5 "strongly agree". These items are grouped into 30 indicators, which are taken as a reference in the results section, and 4 dimensions: effectiveness, efficiency, operability, and satisfaction.

Likewise, the quantitative results were complemented by the realisation of two group interviews, one with 3 teachers and another with 11 students. Following González et al. (2010), the use of this technique is intended to learn the evaluation by these key informants about the same dimensions of usability described above (effectiveness, efficiency, operability, and satisfaction), as well as detect possible improvements for the application.

Participants completed the questionnaire after completing the SL tasks with the SLApp application, at the end of the trial session for each application. The data analysis from the usability questionnaire was carried out in accordance with the statistical procedure described by Boone and Boone (2012). Interviews were conducted in subsequent sessions to the questionnaires, and these were tape recorded, transcribed, and coded.

\section{RESULTS}

The following describes the quantitative and qualitative results, combining the scores of the questionnaire with a narrative analysis of the interviews, based on the registered feedback from teachers and students, in a contextualised and interpreted way (Gil-Flores, 1993).

As we see in Table 1, on a general level all the mean scores, except for item (S16), have values greater than 2.5 . 


\section{Table 1}

Descriptive results of the elements usability consists of on using the SL mobile App in SL intervention.

\begin{tabular}{lll}
\hline ELEMENTS OF USABILITY & MEAN & $\%$ \\
\hline S1. Multimedia usage & 3.02 & 60.45 \\
S2. Appropriate feedback & 3.19 & 63.73 \\
S3. Screen orientation & 3.59 & 71.78 \\
S4. Navigation & 3.54 & 70.72 \\
S5. Main menu & 2.83 & 56.59 \\
S6. Pedagogic feedback & 3.45 & 69.09 \\
S7. Voice instructions & 3.38 & 67.58 \\
S8. Virtual keyboard & 3.88 & 77.58 \\
S9. Ease understanding output & 3.59 & 71.82 \\
S10. Loading application & 2.76 & 55.15 \\
S11. Response time & 2.82 & 56.36 \\
S12. Task effort & 3.21 & 64.11 \\
S13. Finding help & 2.75 & 55.00 \\
S14. Usefulness of help & 3.49 & 69.73 \\
S15. Tutorials & 3.20 & 63.94 \\
S16. Appropriate language & 2.40 & 47.92 \\
S17. Appropriate content & 3.65 & 73.03 \\
S18. Ease of learning & 2.73 & 54.62 \\
S19. Educational value & 3.49 & 69.89 \\
S20. Suitability for all users & 3.09 & 61.86 \\
S21. Learning activities & 3.31 & 66.25 \\
S22. Performance assessment & 3.42 & 68.41 \\
S23. Error messages & 3.21 & 64.20 \\
S24. Ease of readability & 3.64 & 72.88 \\
S25. Satisfaction with text & 2.64 & 52.77 \\
S26. Engagement & 3.55 & 71.08 \\
S27. Screen layout & 2.81 & 56.19 \\
S28. Attractive screen design & 3.09 & 61.74 \\
S29. Interface colours & 2.77 & 55.49 \\
S30. Icons and buttons & 3.59 & 71.82 \\
\hline & & \\
\hline
\end{tabular}

The items with a higher score correspond, on the one hand, to technical aspects, such as the availability of the virtual keyboard to enter the textual information in the different items (S8, with an average of 3.88 out of 5 and $77.58 \%$ ), screen orientation (S3, 3.59 and $71.78 \%$ ) or the icons and buttons (S30, 3.59 and 71.82\%). Beyond the technological sphere, the appropriateness of content in the application (S17, 3.65 and 73.03\%) and the ease of readability (S24, 3.64 and $72.88 \%)$ also stand out.

On the other hand, the items with the lowest scores are the interface colours (S29), with 2.77 (55.49\%), and the screen layout (S27), with 2.81 (56.19\%), which refer to the visual style of the graphic environment. The SL mobile App does not have music and uses blue and white tones, making its environment too basic and simple. This fact was highlighted in the interview with students, who stressed that this had not pleased or motivated them. However, the value with the lowest score is the one that refers to the language used in the application (S16), with an average score of 2.40 and a percentage of $47.92 \%$, highlighting the difficulty in understanding the instructions displayed on the screen in some cases. 
In Figure 4, we can observe the average group scores of the four dimensions.

\section{Figure 4}

Mean scores of the 4 usability dimensions.

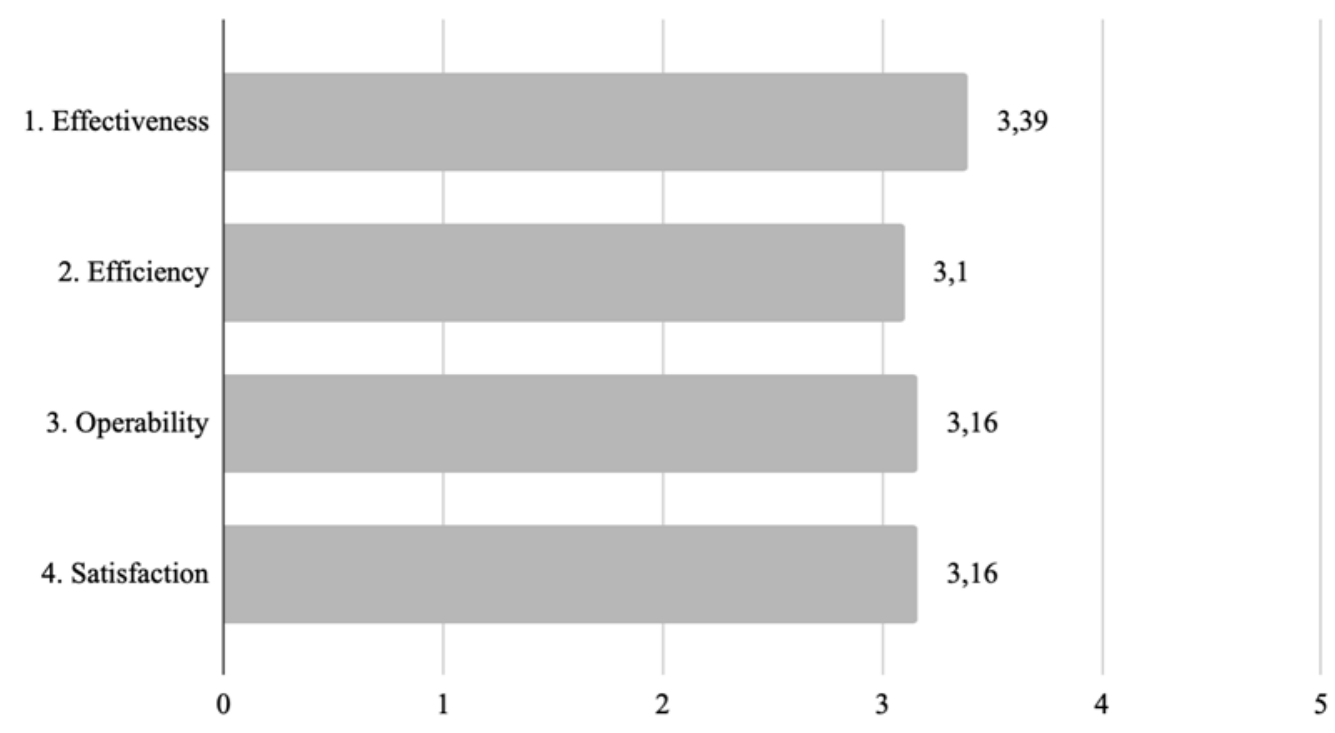

At the technical level, it was also emphasised that the interface intended for teachers was more useful seen from the computer than from mobile devices, and that made the teachers require a computer to be able to give student feedback, missing out on the immediacy and the instantaneous nature of the app. We can see this appreciation reflected in the descriptive results in table 1, as for example in the element $\mathbf{5 6}$, pedagogical feedback, which has a score of $69.09 \%$. On the other hand, students also pointed out that the group interview tool did not edit the response several times. If, for example, an option had been selected by mistake, or the answer had been simply rethought, reworking was not possible until the teacher reviewed the activity and offered them the opportunity to redo it.

At the educational level, the interviewed teachers also pointed out that they had had difficulties in assessing the activities of students, because the application did not correctly alert them to submitted work and did not distinguish between the tasks that were pending correction. This fact, according to the interviewees, caused the teaching staff to spend a lot of time reviewing the tasks students handed in, and problems were even detected in the evaluation of some activities arising from this confusion. Similarly, the students high-lighted the large number of competencies this methodology worked on. This can certainly be interpreted positively, but it also has an opposite reading as being overly complicated to manage the sheer volume of information on the mobile device screen, as can be seen in the results of the questionnaire as well (S25).

\section{CONCLUSIONS}

In today's society, marked especially using technologies, we not only need to train digitally competent students but, in turn, develop civic and citizen-ship skills. A methodology that lets 
these develop is SL, especially in teacher training. However, the experiences of introducing technology into this type of methodologies are still scarce.

This article has aimed to describe the technical and educational characteristics of a mobile application for working on SL projects using the potential of mobile devices. To do this, it presents the results of the development and evaluation of the usability of the SL mobile App, in an educational intervention with SL, in Early Childhood Education and Primary Education Teaching Degrees.

According to the results, in general the application worked correctly at both the technical and educational levels in the 4 dimensions that make up usability: effectiveness, efficiency, operability and satisfaction. However, some especially less valued elements were detected, which should be reviewed in later versions, and which form part of the design principles for the possible development of similar applications in other contexts.

On the one hand, at the technical level, current applications must have an attractive design and interface for the user. Although, at the educational level, content is often prioritised over these aspects, current students, being part of a digital generation, are accustomed to using applications that display high-quality multimedia (Kennedy et al., 2007). One of the concerns that the investigating team had at the beginning of the study was the possible existing digital divide, that a student might not have a powerful enough mobile device. However, after the implementation of the study, it was observed that the entire participating student body had this technology, and that the limitation of the study was due to having only the Android version of the application at that present time. Extending these capabilities to other mobile operating systems will be one of the prospective lines of development for future studies.

On the other hand, at the educational level, the application served to perform cooperative and motivating activities, especially because it allowed for group work, interacting with the tutors from their own mobile phones, uploading videos and audios of the activities carried out by students and recording the progress of their activity following the ideas of Ciampa (2014). In this sense, the possibility of instantaneous, interactive communication, in line with the suggestions made by Ozdamli and Uzumbaylu (2014), is one of the strengths of the project, as evidenced by the results of the questionnaire and discussion groups. However, being extensive activities of a certain complexity managed from a small screen, there are some existing aspects that require consideration, such as the capacity to redo errors or edit the information of already submitted activities or expand the possibilities of feedback and immediacy from the mobiles themselves. The possibility of receiving notifications, of using desktop or mobile versions indistinctly, and the possibility of an instant messaging chat will be some of the aspects that will be analysed in future developments.

In summary, the mobile application presented here allows us to continue moving towards an eSL (Dailey-Hebert et al., 2008), a modality in which the service and/or learning takes place partially or totally online. It allows us to "be present" in different places at the same time, overcoming space-time barriers, such as the time incompatibility of teachers to be in each session, without losing immediacy and feedback. It also allows teachers to maintain a closer and more fluid contact with the collaborating entities, something that is essential in SL. Having an application designed ad-hoc from SL approaches, allows us to overcome the limitations of 
more conventional approaches and open new horizons towards hybrid modalities, very suitable for participants that in other circumstances would have serious difficulties to participate.

As in all investigations, the present study also contains certain limitations. In addition to those listed above, such as being available exclusively for Android versions, it should also be noted that in this phase of the EDR study, the evaluation of the tool has been limited to the technological and educational usability aspects, within a local scope. In subsequent studies, what educational implications this type of intervention may have should also be examined, in a more global scenario, in terms of SL, and the development of civic and digital competences.

\section{ACKNOWLEDGEMENT}

This work has been carried out by financing the following projects: "UJI-A2019-01 Formació de professorat amb aprenentatge-servei a l'era digital: impacte social i evolució tecnològica" and "GVA/2019/100 Disseny i desenvolupament d'una App mòbil per a la millora del aprennentageservei en la formació inicial docente."

\section{REFERENCES}

Boone, H.N., \& Boone D. A. (2012). Analyzing Likert data. Journal of Extension, 50(2), 1-5. https://archives.joe.org/joe/2012april/pdf/JOE_v50_2tt2.pdf

Calvo-Bernardino, A., \& Mingorance-Arnáiz, A. C. (2009). La estrategia de las universidades frente al Espacio Europeo de Educación Superior. Revista Complutense de Educación, 20(2), 319-342. http://hdl.handle.net/10637/6921

Camacho, M., \& Esteve, F. (2018). El uso de las tabletas y su impacto en el aprendizaje. Una investigación nacional en centros de Educación Primaria. Revista de Educación, 379, 170-191. https://doi.org/10.4438/1988-592X-RE-2017-379-366

Carrington, S., \& Saggers, B. (2008). Service-learning informing the development of an inclusive ethical framework for beginning teachers. Teaching and Teacher Education, 24(3), 795806. https://doi.org/10.1016/j.tate.2007.09.006

Chambers, D. J., \& Lavery, S. (2012). Service-learning: a valuable component of pre-service teacher education. Australian Journal of Teacher Education, 37(4), 128-137.

Chiva-Bartoll, Ó., \& Gil-Gómez, J. (2018). Aprendizaje-servicio universitario: Modelos de intervención e investigación en la formación inicial docente. Ediciones Octaedro.

Chou, C.C., Block, L., \& Jesness, R. (2012). A case study of mobile learning pilot project in K-12 schools. Journal of Educational Technology Development and Exchange, 5(2), 11-26.

Ciampa, K. (2014). Learning in a mobile age: an investigation of student motivation. Journal of Computer Assisted Learning, 30(1), 82-96. https://doi.org/10.1111/jcal.12036 
Conner, J. O. (2010). Learning to unlearn: How a service-learning project can help teacher candidates to reframe urban students. Teaching and Teacher Education, 26(5), 11701177. https://doi.org/10.1016/j.tate.2010.02.001

Dailey-Hebert, A., Donelli-Salee, E., \& Dipadova-Stocks L., N. (2008). Service E-Learning: Educating for Citizenship. Information Age Publishing.

Dede, C., Nelson, B., Ketelhut, D. J., Clarke, J., \& Bowman, C. (2004). Designbased research strategies for studying situated learning in a multiuser virtual environment. In Proceedings of the 6th international conference on learning sciences (pp. 158-165).

de Vries, M. J. (2016). Teaching about technology: an introduction to the philosophy of technology for non-philosophers. Springer.

Durall, E., Gros, B., Maina, M. F., Johnson, L., \& Adams, S. (2012). Perspectives tecnològiques: educació superior a Iberoamèrica 2012-2017. The New Media Consortium. http://hdl.handle.net/10609/17361

Eshed E. (2014). On Designing Mobile Education Apps. Citizentekk.

Esteve, F., Castañeda, L., \& Adell, J. (2018). Un modelo holístico de competencia docente para el mundo digital. Revista Interuniversitaria de Formación del Profesorado, 32(1). http://aufop.com/aufop/revistas/indice/impresa/206

European Commission. (2018). Council Recommendation of 22 May 2018 on key competences for lifelong learning (Text with EEA relevance) (2018/C 189/01). Official Journal of the European Union. https://eur-lex.europa.eu/legalcontent/EN/TXT/PDF/?uri=CELEX:32018H0604(01)\&from=EN

Ferrari, A. (2012). Digital competence in practice: An analysis of frameworks. European Commission, Joint Research Centre (JRC). doi:10.2791/82116

Galvan, C., \& Parker, M. (2011). Investigating the reciprocal nature of service-learning in physical education teacher education. Journal of Experiential Education, 34(1), 55-70. https://doi.org/10.1177/105382591103400105

García, R., Gozálvez, V., Vázquez, V., \& Escámez, J. (2010). Repensando la Educación: cuestiones $y$ debates para el siglo XXI. Brief Ediciones.

Gikas, J., \& Grant, M. M. (2013). Mobile computing devices in higher education: Student perspectives on learning with cellphones, smartphones \& social media. The Internet and Higher Education, 19, 18-26. https://doi.org/10.1016/i.iheduc.2013.06.002

Gil-Flores, J. (1993). La posición del profesorado ante el cambio educativo. Un escalamiento multidimensional no métrico de los discursos sobre la Reforma. Revista Investigación educativa, 21, 67-82.

González, J., Espuny, C. y Gisbert, M. (2010). La evaluación cero de la competencia nuclear digital en los nuevos grados del EEES. @tic. Revista d'Innovació Educativa, 4, 13-20. 
Himelein, M., Passman, L., \& Phillips, J. M. (2010). College teaching and community outreaching: Service learning in an obesity prevention program. American Journal of Health Education, 41(6), 368-378. https://doi.org/10.1080/19325037.2010.10599166

Keinonen, T. (1998). One-dimensional usability - Influence of usability on consumers' product preference. Gummerus.

Kennedy, G., Dalgarno, B., Gray, K., Judd, T., Waycott, J., Bennett, S. J., Maton, K., Krause, K., Bichop, A., Chand, R. \& Churchwood, A. (2007). The net generation are not big users of Web 2.0 technologies: Preliminary findings. Proceedings ascilite Singapore, 517-525. https://ro.uow.edu.au/edupapers/920

Krumsvik, R. (2009). Situated learning in the network society and the digitised school. European Journal of Teacher Education, 32(2), 167-185.

Kunjachan, M.A.C (2011). Evaluation of Usability on Mobile User Interface. University of Washington, Bothell.

Hall, R., Atkins, L., \& Fraser, J. (2014). Defining a selfevaluation digital literacy framework for secondary educators: The digilit lecister project. Research in Learning Technology, 22. DOI: http://dx.doi.org/10.3402/rlt.v22.21440

Mac Callum, K., Jeffrey, L., \& Kinshuk. (2014). Factors impacting teachers' adoption of mobile learning. Journal of Information Technology Education: Research, 13, 141-162. https://bit.ly/3cSo0B1

Maravé-Vivas, M., Gil-Gómez, J., \& Trilles, M. (2019). Aprendizaje-Servicio en la Didáctica de la Expresión Corporal: efectos sobre la empatía del alumnado universitario. Publicaciones, 49(4), 111-125. http://dx.doi.org/10.30827/publicaciones.v49i4.11731

Miller, K., \& Gonzalez, A. M. (2010). Domestic and international service-learning experiences: A comparative study of pre-service teacher outcomes. Issues in educational research, 20(1), 29-38.

Mylläri, J., Kynäslahti, H., Vesterinen, O., Vahtivuori-Hänninen, S., Lipponen, L., \& Tella, S. (2011). Students' pedagogical thinking and the use of ICTs in teaching. Scandinavian Journal of Educational Research, 55(5), 537-550. https://doi.org/10.1080/00313831.2011.555920

Nawaz, A., \& Kundi, G. M. (2010). Digital literacy: An analysis of the contemporary paradigms. International Journal of Science and Technology Education Research, 1(2), 19-29. https://doi.org/10.5897/IJSTER.9000011

Nokelainen, P. (2006). An empirical assessment of pedagogical usability criteria for digital learning material with elementary school students. Educational Technology \& Society, 9(2), 178-197. https://www.ds.unipi.gr/et\&s/journals/9 2/15.pdf 
Ozdamli, F., \& Uzunboylu, H. (2015). M-learning adequacy and perceptions of students and teachers in secondary schools. British Journal of Educational Technology, 46(1), 159172. https://doi.org/10.1111/bjet.12136

Palma, M. G. (2019). Educación y exclusión digital: los falsos nativos digitales. Revista de estudios socioeducativos. ReSed, (7), 27-41. https://bit.ly/3FVXH9M

Palomares, A. (2011). El modelo docente universitario y el uso de nuevas metodologías en la enseñanza, aprendizaje y evaluación. Revista de educación, 355, 591-604. http://hdl.handle.net/11162/81482

Plomp, T. \& Nieveen, N. (2009). An introduction to educational design research. Enschede: Netherlands Institute for curriculum development.

Print, M. (2003). Estrategias de enseñanza para la educación cívica y ciudadana en el siglo XXI. Estudios sobre Educación, 4, 7-22.

Ramos, A.I., Herrera, J.A., y Ramírez, M.S. (2009). Desarrollo de habilidades cognitivas con aprendizaje móvil: un estudio de caso. Comunicar, 34, 201-202. https://doi.org/10.3916/ C34- 2010-03-20

Salaburu, P., Ginés-Mora, J., \& Haug, G. (2011). España y el proceso de Bolonia: un encuentro imprescindible. Academia Europea de Ciencias y Artes. https://bit.ly/3DOlulL

Santágueda-Villanueva, M., Maravé-Vivas, M., Esteve-Mon, F., \& Pallares-Piquer, M. (2019). Design of a mobile application for the improvement of a service learning project in the initial teacher training. In J. Vopava, V. Douda, R. Kratochvil \& M. Konecki (Ed.) Proceedings of MAC 2019 (pp. 168-176) Prague, Czech Republic: MAC Prague Consulting.

Santos-Rego, M. A. \& Lorenzo, M. (eds.) (2012). Estudios de Pedagogía intercultural. Octaedro.

Santos-Rego, M. A., Mella-Núñez, I., \& Sotelino-Losada, A. (2020). Movilidad y TIC en aprendizaje-servicio: perspectivas para una sociedad global y tecnológica. RIED. Revista Iberoamericana de Educación a Distancia, 23(1), 67-84. http://dx.doi.org/10.5944/ried.23.1.24180

Seffah, A. Donyaee M., Kline R.B., \& Padda H.K. (2006) Usability measurement and metrics: A consolidated model. Software Quality Journal 14.2, 159-178. DOI https://doi.org/10.1007/s11219-006-7600-8

Siemens, G. (2004). Conectivismo: Una teoría de aprendizaje para la era digital. https://bit.ly/3rde3X8

Soska, T. M., Sullivan-Cosetti, M., y Pasupelti, S. (2010). Service-learning: Community engagement and partnership for integrating teaching, research, and service. Journal of Community Practice, 18, 139-147. 
Tahir, R., \& Arif, F. (2014). A Measurement Model Based on Usability Metrics for Mobile Learning User Interface for Children. The International Journal of E-Learning and Educational Technologies in the Digital Media (IJEETDM), 1(1), 16-31.

Tessmer, M. (2013). Planning and conducting formative evaluations. Routledge.

Touriñán, J. M. (2007). Integrar la escuela en la Sociedad de la Información: desmitificar la perspectiva TIC y orientar la educación electrónica. Tecnología y comunicación educativas, 21(45), 42-68.

Van den Akker, J., Gravemeijer, K., McKenney, S., \& Nieveen, N. (Eds.). (2006). Educational design research. Routledge.

Villa, A., \& Poblete, M. (2011). Evaluación de competencias genéricas: principios, oportunidades y limitaciones. Bordón. Revista de pedagogía, 63(1), 147-170. https://bit.ly/3EOzONE

Vuorikari, R., Punie, Y., Carretero, S., \& Van den Brande, L. (2016). DigComp 2.0: The Digital Competence Framework for Citizens. Update Phase 1: The conceptual reference model. Luxembourg Publication Office of the European Union. https://publications.jrc.ec.europa.eu/repository/handle/JRC101254

Zorrilla, L. (2017). Diseño y aplicación del programa socioemocional Siente Jugando en alumnado de Educación Primaria mediante la metodología Aprendizaje Servicio (Tesis doctoral). Universitat Jaume I, Castellón.

\section{To cite this work:}

Santágueda Villanueva, M., LLopis Nebot, M. Á, \& Esteve Mon, F. M. (2021). A mobile application for working on university service learning: usability, adequacy and perceptions of usefulness. Edutec. Revista Electrónica De Tecnología Educativa, (78) 22-37. https://doi.org/10.21556/edutec.2021.78.2231 